\title{
MENCIPTAKAN PENGALAMAN KONSUMENDENGAN EXPERIENTIAL MARKETING
}

\author{
Yoyon Safrianto \\ Universitas Teuku Umar \\ Email: Yoyonsafrianto@gmail.com
}

\begin{abstract}
Experiential marketing gives customers an opportunity to engage and interact with brands, products, and services in sensory ways that provide the icing on the cake of providing information. Personal experiences help people connect to a brand and make intelligent and informed purchasing decisions. The term "experiential marketing" refers to actual costomers esperiences with the brand/product/services that drive sales and increase brand image and awareness through sense, feel, think, act, and relate to Company and Brands. It's difference between telling people about features of product or service and letting them experience the benefits for themselves. When done right, it's the most powerfull tool out there to win brand loyalty.
\end{abstract}

Keywords: sense, feel, think, act, and relate

\section{PENDAHULUAN}

Pada era kompetisi yang makin ketat ini, keberhasilan menciptakan persepsi positif di benak konsumen merupakan faktor penting dalam kesuksesan produk/merek, bahkan mungkin lebih penting daripada keunggulan teknologi. Keunggulan kompetitif dalam fungsi teknis produk adalah penting, tetapi akhirnya yang menentukan produk dapat berhasil di pasar adalah konsumen. Bagaimana menciptakan nilai emosional di produk/merek dan menimbulkan rasa kepemilikan kepada merek tersebut sehingga konsumen bersedia menyisihkan share ofwalletnya untuk produk/merek kita adalah kuncikeberhasilan merek di pasar. Kuncinya adalah menciptakan excellent experience dengan membuat produk bisa dirasakan konsumen. Selama ini pelanggan hanya melihat iklan dan kemasan produk, tetapi tidak bisa merasakan produknya. Jadi, mau tidak mau cara seperti ini ditempuh para produsen sehingga tercipta buzz of word.

Experience secara harafiah diartikan sebagaipengalaman. Tiga puluh tahun lalu, Al Ries dan Jack Trout dalam artikel mereka yang dimuat dalam

Advertising Age yang berjudul The Positioning Era Cometh, mengatakan bahwa perang pemasaranbukanlah di pasar melainkan di benak pelanggan sehingga setiap kegiatan pemasaran selalu dilakukan untuk merebut hati pelanggan lewat produk dan jasa (service) atau yang lazimnya disebut service excellence (Ries and Ries: 2003) Saat ini, hampirsemua penyedia produk dan jasa melakukan apa yang disebut service excellence. Service excellence telah menjadi sebuah konsep dasar yang harus dilakukanseorang pemasar. Saat ini pelanggan mempunyai kekuatan untuk memilih (Winarko: 2003).

Banyak iklan di majalah dan koran yang memuat beberapa produk yang dengan gencarnya memberitakan dirinya sebagai produk yang telah memuaskan pelanggan dan memperoleh penghargaan Satisfaction Award. Namun, kepuasan konsumentidak menjamin konsumen akan loyal pada suatu produk (Smith and Wheeler, 2002). Karena itulah, saat ini kepuasan konsumen tidak lagi cukup untuk sukses dalam dunia pemasaran (Winarko: 2003). 
Pine and Gilmore (1999) mengidentifikasi bahwa penawaran yang diberikan oleh perusahaan kepada pelanggannya dapat berupa komoditi(Commodities), barang (goods), layanan (services), dan pengalaman (experiences). Dahulu, saat era services economy dan service excellence, barang danlayanan yang bagus sudah cukup untuk memuaskan pelanggan. Karena itulah kepuasan pelanggan kemudian menjadi ukuran kesuksesan sebuah merek. Namun kini, kita memasuki era experiential economy. Untuk itulah, produk harus mampu membangkitkan sensasi dan pengalaman yang akan menjadi basis loyalitas pelanggan. Karena pergeseran ini, maka konsep kepuasan pelanggan kini menjadi kurang relevanExperiential Marketing merupakan suatumetode pemasaran yang relatif baru, yang disampaikan ke dunia pemasaran lewat sebuah bukuExperiential Marketing: How to Get Customers to Sense, Feel, Think, Act, and Relate to Your Company and Brands, oleh Bernd H. Schmitt. Schmitt (1999)menyatakan bahwa esensi dari konsep experientialmarketing adalah pemasaran dan manajemen yangdidorong oleh pengalaman.

Dalam bukunya, Schmitt (1999) juga mengemukakan tentang pendekatan features andbenefits (F \& B) dalam pemasaran tradisional. Dalampemasaran tradisional ini, pemasar menganggap konsumen berfikir melalui suatu proses pengambilan keputusan, yang mana masing-masing karakteristik dari suatu produk, baik barang atau jasa, akan memberikan keuntungan yang jelas, dan karakteristik ini dievaluasi oleh pembeli-pembeli potensial (baik pembeli yang telah mengenal produk tersebuat maupun yang belum) . Bagaimanapun juga, Schmitt (1999) mengganggap konsep ini sangat membatasi cara pandang pemasar terhadap pengambilan keputusan yang diambil oleh konsumen, yang melibatkan elemen rasionalitas dan logika, serta aspek emosional dan irasional dalam pembelian.

Experiential marketing dapat sangat bergunauntuk sebuah perusahaan yang ingin meningkatkan merek yang berada pada tahap penurunan, membedakan produk mereka dari produk pesaing, menciptakan sebuah citra dan identitas untuk sebuah perusahaan, meningkatkan inovasi dan membujuk pelanggan untuk mencoba dan membeli produk. Hal yang terpenting adalah menciptakan pelanggan yang loyal

Pelanggan mencari perusahaan dan merek-merek tertentu untuk dijadikan bagian dari hidup mereka. Pelanggan juga ingin perusahaan-perusahaan dan merek-merek tersebut dapat berhubungan dengan hidup mereka, mengerti mereka, menyesuaikan dengan kebutuhan mereka dan membuat hidup mereka lebih terpenuhi. Dalam era informasi, teknologi, perubahan dan pilihan, setiap perusahaan perlu lebih selaras dengan para pelanggan dan pengalaman yang diberikan produk atau jasa mereka.

Tahap awal dari sebuah experientialmarketing terfokus pada tiga kunci pokok:

1. Pengalaman Pelanggan. Pengalaman pelanggan melibatkan panca indera, hati, pikiran yang dapat menempatkan pembelian produk atau jasa di antara konteks yang lebih besar dalam kehidupan.

2. Pola Konsumsi. Analisis pola konsumsi dapat menimbulkan hubungan untuk menciptakan sinergi yang lebih besar. Produk dan jasa tidak lagi dievaluasi secara terpisah, tetapi dapat dievaluasi sebagai bagian dari keseluruhan pola penggunaan yang sesuai dengan kehidupan konsumen. Hal yang terpenting, pengalaman setelah pembelian diukur melalui kepuasan dan loyalitas.

Keputusan rasional dan emosional. Pengalaman dalam hidup sering digunakan untuk memenuhi fantasi, perasaan dan kesenangan. Banyak keputusan dibuat dengan menuruti kata hati dan tidak rasional. Experiential marketing pelangganmerasa senang dengan keputusan pembelian yang telah dibuat. 
Schmitt (1999) memberikan suatu framework alternatif yang terdiri dari dua elemen, yaitu Strategicexpereince modules (SEMs), yang terdiri daribeberapa tipe experience dan Experience producers(ExPros), yaitu agen - agen yang dapat menghantarkan experience ini.Strategic experience modules terdiri dari limatipe, yaitu sense, feel, think, act, dan relate.

\section{Sense}

Sense adalah aspek- aspek yang berwujud dandapat dirasakan dari suatu produk yang dapat ditangkap oleh kelima indera manusia,meliputi pandangan,suara,bau, rasa, dan sentuhan. Sense ini, bagi konsumen, berfungsi untuk mendiferensiasikan suatu produk dari produk yang lain,untuk memotivasi pembeli untuk bertindak, dan untuk membentuk value pada produk atau jasa dalam benak pembeli.

Indera manusia dapat digunakan selama fase pengalaman (pra pembelian, pembelian dan sesudah pembelian) dalam mengkonsumsi sebuah produk atau jasa. Perusahaan biasanya menerapkan unsur sense dengan menarik perhatian pelanggan melalui hal-hal yang mencolok, dinamis, dan meninggalkan kesan yang kuat.

Ada tiga tujuan strategi panca indera (sensestrategic objective): (Schmitt,1999)

1. Panca indera sebagai pendiferensiasi

Sebuah organisasi dapat menggunakan sensemarketing untuk mendiferensiasikan produkorganisasi dengan produk pesaing didalam pasar, memotivasi pelanggan untuk membeli produknya, dan mendistrisbusikan nilai kepada konsumen.

2. Panca indera sebagai motivator

Penerapan unsur sense dapat memotivasi pelanggan untuk mencoba produk dan membelinya.

3. Panca indera sebagai penyedia nilai

Panca indera juga dapat menyediakan nilai yang unik kepada konsumen.

\section{Feel}

Perasaan berhubungan dengan perasaan yang paling dalam dan emosi pelanggan. Iklan yang bersifat feel good biasanya digunakan untuk membuathubungan dengan pelanggan, menghubungkan pengalaman emosional mereka dengan produk atau jasa, dan menantang pelanggan untuk bereaksi terhadap pesan Feel campaign sering digunakan untukmembangun emosi pelanggan secara perlahan. Ketika pelanggan merasa senang terhadap produk yang ditawarkan perusahaan, pelanggan akan menyukai produk dan perusahaan. Sebaliknya, ketika pelanggan merasa tidak senang terhadap produk yang ditawarkan perusahaan, maka konsumen akan meninggalkan produk tersebut dan beralih kepada produk lain. Jika sebuah strategi pemasaran dapat menciptakan perasaan yang baik secara konsisten bagi pelanggan, maka perusahaan dapat menciptakan loyalitas merek yang kuat dan bertahan lama (Schmitt,1999).

Affective experience adalah tingkatpengalaman yang merupakan perasaan yang bervariasi dalam intensitas, mulai dari perasaan yang positif atau pernyataan mood yang negatif sampai emosi yang kuat. Jika pemasar bermaksud untuk menggunakan affective experience sebagai bagian dari strategipemasaran, maka ada dua hal yang harus diperhatikan dan dipahami, yaitu: 
1. Suasana hati (moods), Moods merupakan affective yang tidak spesifik.Suasana hati dapat dibangkitkan dengan cara memberikan stimuli yang spesifik (Schmitt, 1999). Suasana hati merupakan keadaan afektif yang positif atau negatif. Suasana hati seringkali mempunyai dampak yang kuat terhadap apa yang diingat konsumen dan merek apa yang mereka pilih.

2. Emosi (emotion), lebih kuat dibandingkan suasana hati dan merupakan pernyataan afektif dari stimulus yang spesifik, misalnya marah, irihati, dan cinta. Emosi-emosi tersebut selalu disebabkan oleh sesuatu atau seseorang (orang, peristiwa, perusahaan, produk, atau komunikasi).

\section{Think}

Perusahaan berusaha untuk menantang konsumen, dengan cara memberikan problemsolvingexperiences, dan mendorong pelanggan untukberinteraksi secara kognitif dan/atau secara kreatif dengan perusahaan atau produk. Iklan pikiran biasanya lebih bersifat tradisional, menggunakan lebih banyak informasi tekstual, dan memberikan pertanyaan-pertanyaan yang tak terjawabkan

Menurut Schmitt cara yang baik untuk membuat think campaign berhasil adalah (1) menciptakan sebuah kejutan yang dihadirkan baik dalam bentuk visual, verbal ataupun knseptual, (2) berusaha untuk memikat pelanggan dan (3) memberikan sedikit provokasi.

1. Kejutan (surprise)

Kejutan merupakan suatu hal yang penting dalam membangun pelanggan agar mereka terlibat dalam cara berpikir yang kreatif. Kejutan dihasilkan ketika pemasar memulai dari sebuah harapan. Kejutan harus bersifat positif, yang berarti pelanggan mendapatkan lebih dari yang mereka minta, lebih menyenangkan dari yang mereka harapkan, atau sesuatu yang sama sekali lain dari yang mereka harapkan yang pada akhirnya dapat membuat pelanggan merasa senang. Dalam experiential marketing, unsur surprise menempatihal yang sangat penting karena dengan pengalaman- pengalaman yang mengejutkan dapat memberikan kesan emosional yang mendalam dan diharapkan dapat terus membekas di benak konsumen dalam waktu yang lama.

2. Memikat (intrigue)

Jika kejutan berangkat dari sebuah harapan, intrigue campaign mencoba membangkitkan rasaingin tahu pelanggan, apa saja yang memikat pelanggan. Namun, daya pikat ini tergantung dari acuan yang dimiliki oleh setiap pelanggan. Terkadang apa yang dapat memikat seseorang dapat menjadi sesuatu yang membosankan bagi orang lain, tergantung pada tingkat pengetahuan, kesukaan, dan pengalam pelanggan tersebut.

3. Provokasi (provocation)

Provokasi dapat menimbulkan sebuah diskusi, atau menciptakan sebuah perdebatan. Provokasi dapat beresiko jika dilakukan secara tidak baik dan agresif (Shmitt, 1999). 
Tindakan yang berhubungan dengan keseluruhan individu (pikiran dan tubuh) untuk meningkatkan hidup dan gaya hidupnya. Pesan-pesan yang memotivasi, menginspirasi dan bersifat spontan dapat menyebabkan pelanggan untuk berbuat hal-hal dengan cara yang berbeda, mencoba dengan cara yang baru merubah hidup mereka lebih baik.

\section{Relate}

Relate menghubungkan pelanggan secaraindividu dengan masyarakat, atau budaya. Relate menjadi daya tarik keinginan yang paling dalam bagi pelanggan untuk pembentukan self-improvement, status socio-economic, dan image. Relate campaign menunjukkan sekelompok orang yang merupakan target pelanggan dimana seorang pelanggan dapat berinteraksi, berhubungan, dan berbagi kesenangan yang sama.

Kelima tipe dari experience ini disampaikan kepada konsumen melalui experience provider. Agen-agen yang bisa menghantarkan experience ini adalah

1. Komunikasi, meliputi iklan, komunikasi perusahaan baik internal maupun eksternal, dan public relation.

2. Identitas dan tanda baik visual maupun verbal, meliputi nama, logo, warna, dan lain-lain.

3. Tampilan produk, baik desain, kemasan, maupu penampakan.

4. Co-branding, meliputi even-even pemasaran,sponsorship, aliansi dan rekanan kerja, lisensi, penempatan produk dalam film, dan sebagainya.

5. Lingkungan spatial, termasuk desain kantor, baik interior maupun eksterior, outlet penjualan, ekshibisi penjualan, dan lain-lain.

6. Web sites

7. Orang, meliputi penjual, representasi perusahaan, customer service, operator call centre, danlainnya.

Idealnya, sebuah perusahaan yang ingin menerapkan experiential marketing mampu memberikan experience yang integral, yaitu menyampaikan kelima elemen experience melalui Experience Provider. Inilah yang disebut oleh Schmitt (1999) sebagai holistic. Dalam membangun sebuah pendekatan experiential marketing, Schmitt (1999) menghubungkannya dengan teori hierarki Maslow. Schmitt (1999) menyebutkan: If you start fromscratch, the recommended sequence is the order in which I discussed the SEMs in this book: SENSE FEEL THINK ACT RELATE. SENSE attracts attention and motivates. FEEL creates an affectives bond and makes the experience personally relevant and rewarding. THINK adds a permanent cognitive interest to the experience. ACT induces a behavioral commitment. Loyalty, and a view to the future. RELATE goes beyond the undividual experience and makes it meaningful in a broader social context.

Selain itu, Shmitt (1999) juga mengemukakan beberapa cara untuk membentuk dan mengelola merek yang experiential. Konsep ini dirangkum menjadi poin-poin dalam Experintial Branding, 10 Rules to Create and Manage Experiential Brands, mendalam, yang akan terus-menerus membangkitkan 
kenangan, sehingga konsumen menjadi loyal. Karakter ini adalah suatu elemen kecil yang sangat mengesankan, membingkai, dan merangkum keseluruhan experience yang dirasakan konsumen.

1. Experiences don't just happen; they need to be experiential marketing: (Hidayat, 2007 \& Kertajaya, planned. Dalam proses perencanaan, seorang 2007) pemasar harus kreatif, memanfaatkan kejutan, intrik, dan bahkan provokasi

2. Think about the customer experience first.

Setelah itu, barulah seorang pemasar dapat menentukan karakteristik-karakteristik fungsional dari sebuah produk dan manfaat dari merek yang ada

3. Be obsessive about the details of the experience. menyambangi konsumennya. Kehadiran RCC adalahKonsep pemuasan kebutuhan konsumen tradisional melewatkan unsur-unsur sensori, perasaan hangat yang dirasakan konsumen, serta „cuci otak" konsumen, yang meliputi pemuasan seluruh tubuh dan seluruh pikiran konsumen. Shmitt (1999) menyebutnya Exultate Jubilate, yang berarti kepuasan yang amat sangat.

4. Find the "duck" for your brand. Maknanya,seorang pemasar diharapkan mampu memberikan suatu karakter yang memberikan kesan yang wujud kepedulian Citra yang ingin membantu perempuan Indonesia meraih kecantikan jiwa -raga. Selain itu, Citra juga mencerminkan cita rasa kecantikan lokal wanita Indonesia yang digempur produk perawatan kulit dan muka dari luar negeri. Citra mengedepankan bahan baku tradisional yang diolah dan dikemas secara moderen.

5. Think consumption situation, not product.

6. Strive for "holistic experiences" Holistic, sepertiyang telah disebutkan diatas, adalah sebuah perasaan yang luar biasa, menyentuh hati, menantang intelegensi, relevan dengan gaya hidup konsumen, dan memberikan hubungan yang mendalam antar konsumen.

7. Profile and track experiential impact with the Experiential Grid.

8. Use methodologies eclectically. Metodepenelirian dalam pemasaran bisa berbentuk kuantitatif maupun kualitatif, verbal maupun visual, dan di dalam maupun di luar laboratorium. Pemasar dalam meneliti harus eksploratif dan kreatif, serta menomorsekiankan tentang reliabilitas, validitas, dan kecanggihan metodologinya.

9. Consider how the experience changes. Pemasarterutama harus memikirkan hal ini ketika perusahaan memutuskan untuk memperluas merek ke dalam kategori baru.

10. Add dynamism and "dionysianism" to your company and brand. Kebanyakan organisasi danperusahaan pemilik merek terlalu takut, terlalu perlahan, dan terlalu birokratis. Untuk itulah dionysianism perlu diterapkan. Dionysianism adalah kedinamisan, gairah, dan kreativitas

\section{Beberapa perusahaan yang menggunakan metode experiential marketing}

\section{PT Unilever Indonesia Tbk}

Perusahaan ini memperkenalkan wahana bagi konsumennya untuk menggali lebih jauh berkaitan dengan salah satu produk perawatan kulitnya, Citra. Wahana yang dikenal dengan Rumah Cantik Citra (RCC) ini memang tidak menetap disatu tempat, melainkan berkeliling keberbagai kota untuk wujud kepedulian Citra yang ingin membantu perempuan Indonesia meraih kecantikan jiwa -raga. Selain itu, Citra juga mencerminkan cita rasa kecantikan lokal wanita Indonesia yang digempur produk perawatan 
kulit dan muka dari luar negeri. Citra mengedepankan bahan baku tradisional yang diolah dan dikemas secara moderen. Hal ini sesuai dengan semangat wanita Indonesia yang semakin modern tanpa harus menanggalkan kecantikan khas Indonesianya.

RCC adalah bagian dari aktivitas brand imagebuilding Citra. Tujuannya, untuk memperkuat citramerek Citra dibenak konsumen, khususnya pecinta produk perawatan kulit dan muka lokal. Citra bukanlah produk perawatan tradisional belaka, tapi juga sudah dikemas dan diolah secara modern seiring dengan kemajuan pola berpikir dan sikap wanita Indonesia itu sendiri yang semakin mandiri dan modern, alasan utama kehadiran RCC, agar konsumen semakin kenal produk-produk Citra dan merasakan efek langsungnya pada kulit dengan menikmai berbagai perawatan spa dan, tentu saja meningkatkan penjualan.

RCC menyediakan berbagai perawatan spa seperti hand and foot spa, body massage \& scrub, totok wajah dan konsultasi kulit. Berbagai macam perawatan tersebut dapat dinikmati dengan membeli atau membawa produk Citra. Disamping itu pada Sabtu dan Minggu pengunjung dapat mengikuti kelas yoga, manajemen stress, aura healing, danhipnoterapi gratis.

Jika dibandingkan, harga jual per item di RCC dengan supermarket tidak jauh berbeda. Namun, di RCC konsumen dapat merasakan sensasi dan menikmati suasana. Disini konsumen jadi lebih mengerti produk Citra. Apalagi konsumen sering ikut kelas- kelas gratis yang ditawarkan citra, khususnya stress manajemen dan hipnoterapi.

\section{PT Hewlett-Packard Indonesia (HPI)}

HPI mulai menerapkan konsep yang dikemukakan Schmitt. Bahkan apa yang dilakukan HPI jauh lebih ekstrem ketimbang Unilever. Lewat HP Xperience Zone, HPI menyediakan tempat khusus di Blitz Megaplex, Grand Indonesia, bagi calon konsumennya untuk mengetahui dan mencoba secara langsung produk-produk mereka. Disini konsumen dapat mencoba berbagai produk terbaru tanpa harus ada paksaan untuk membeli, karena memang tidak ada aktivitas jual beli di toko ini. Keberadaannya hanya untuk memberikan pengalaman dan sekaligus membangun citra HP. Konsumen dapat mencoba dan bertanya berbagai hal yang berkaitan dengan produk.

HP Xperience Zone sejalan dengan tema kampanye global HP yang diluncurkan dua tahun lalu, Personal Again. Lewat HP Xperience Zone, merekaingin lebih mendekatkan diri dengan konsumen. Selama ini, walau memiliki cakupan produk yang sangat lengkap, baik untuk personal maupun korporat, citra HP masih sangat korporat. Untuk itu, diberikan wadah atau sarana agar orang merasa personal.

Fasilitas HP Xperience Zone menggunakan sistem membership. Untuk menjadi anggota, cukup mengisi aplikasi yang tersedia di HP Xperience Zone. Selanjutnya, tinggal login dengan menggunakan user id dan password yang didaftarkan. Tidak ada biayauntuk itu. Pola keanggotaan digunakan agar HPI bisa lebih mengetahui siapa konsumennya. Cara mendekatkan diri kepada konsumen tanpa harus tahu siapa konsumen dan apa aspirasi, dan merangsang anggotanya, HPI menawarkan berbagai bentuk program reward point yang dapat ditukarkan dengan fasilitas di dalam ataupun di luar Blizt.

Selain membidik konsumen perorangan, HP Xperience Zone ditujukan pula bagi kalangan usaha kecil-menengah. Hanya saja, perlakuannya sedikit berbeda. Untuk UKM hanya berdasarkan undangan. Mekanismenya seperti workshop. HPI akan mengundang 10- 15 perusahaan dari industri yang punya kebutuhan yang sama/mirip, dan produk yang ditampilkan akan disesuaikan dengan jenis UKM yang diundang. Acara ini akan dilakukan setidaknya dua kali sebulan. Hal ini untuk 
memanfaatkan waktu luang di siang hari. Biasanya konsumen perorangan lebih banyak datang pada sore dan malam hari.

Saat ini, UKM yang sudah bersentuhan dengan tegnologi informasi masih relatif kecil. Karena itu, HPI berani mengambil inisiatif tersebut walaupun mereka sadar bahwa HP hanyalah salah satu bagian dari TI. HP ingin menciptakan smart office bagi UKM, Ujarnya. Untuk mencapai tujuan itu, HPI menjajaki kerja sama dengan berbagai pihak, seperti perusahaan aplikasi (berkaitan dengan produktivitas) serta perbankan dan finansial (berkaitan denganaffordability).

\section{Rajawali Hiyoto}

Produsen beberapa merek cat ini bahkan memimpin pasar di beberapa area menciptakan konsep dapur cat yang dinamakan Ralston "De Verfkeuken”. Dapur cat ini dibuat untuk keluar dari persainagn cat di Indonesia yang menjadi produk komoditas. Tiap-tiap merek tidak memiliki diferensiasi yang unik, dan konsumen mungkin tak memperhitungkan lagi keunikan masing-masing. Sehingga perang harga di produk cat pun tidak bisa dihindari, seperti halnya produk komoditas lain. Untuk menghindari perang harga itu, dapur cat pun di ciptakan, yang memberikan pengalaman (experience) unik bagi konsumennya.

Di Ralston “De Verfkeuken”, konsumen dapat membuat pilihan cat menurut seleranya. Dapur cat ini menyediakan mesin yang memungkinkan konsumen membuat cat serta jasa konsultasi bagi konsumen. Tersedia juga coffee shop, perpustakaan, dan taman bermain bagi anggota keluarga konsumen yang menemani sehingga mereka merasa nyaman. Konsumen dapat menimbang catnya, mengoperasikan mesin yang men-customized warna cat sesuai dengan keinginan dan memilih aroma yang mereka sukai. $i d$ dan password yang didaftarkan. Tidak ada biayauntuk itu. Pola keanggotaan digunakan agar HPI bisa lebih mengetahui siapa konsumennya. Cara mendekatkan diri kepada konsumen tanpa harus tahu siapa konsumen dan apa aspirasi, dan merangsang anggotanya, HPI menawarkan berbagai bentuk program reward point yang dapat ditukarkan dengan fasilitas di dalam ataupun di luar Blizt.

Selain membidik konsumen perorangan, HP Xperience Zone ditujukan pula bagi kalangan usaha kecil-menengah. Hanya saja, perlakuannya sedikit berbeda. Untuk UKM hanya berdasarkan undangan. Mekanismenya seperti workshop. HPI akan mengundang 10- 15 perusahaan dari industri yang punya kebutuhan yang sama/mirip, dan produk yang ditampilkan akan disesuaikan dengan jenis UKM yang diundang. Acara ini akan dilakukan setidaknya dua kali sebulan. Hal ini untuk memanfaatkan waktu luang di siang hari. Biasanya konsumen perorangan lebih banyak datang pada sore dan malam hari.

Saat ini, UKM yang sudah bersentuhan dengan tegnologi informasi masih relatif kecil. Karena itu, HPI berani mengambil inisiatif tersebut walaupun mereka sadar bahwa HP hanyalah salah satu bagian dari TI. HP ingin menciptakan smart office bagi UKM, Ujarnya. Untuk mencapai tujuan itu, HPI menjajaki kerja sama dengan berbagai pihak, seperti perusahaan aplikasi (berkaitan dengan produktivitas) serta perbankan dan finansial (berkaitan denganaffordability).

\section{Rajawali Hiyoto}

Produsen beberapa merek cat ini bahkan memimpin pasar di beberapa area menciptakan konsep dapur cat yang dinamakan Ralston "De Verfkeuken". Dapur cat ini dibuat untuk keluar dari persainagn cat di Indonesia yang menjadi produk komoditas. Tiap-tiap merek tidak memiliki 
diferensiasi yang unik, dan konsumen mungkin tak memperhitungkan lagi keunikan masing-masing. Sehingga perang harga di produk cat pun tidak bisa dihindari, seperti halnya produk komoditas lain. Untuk menghindari perang harga itu, dapur cat pun di ciptakan, yang memberikan pengalaman (experience) unik bagi konsumennya.

Di Ralston "De Verfkeuken", konsumen dapat membuat pilihan cat menurut seleranya. Dapur cat ini menyediakan mesin yang memungkinkan konsumen membuat cat serta jasa konsultasi bagi konsumen. Tersedia juga coffee shop, perpustakaan, dan taman bermain bagi anggota keluarga konsumen yang menemani sehingga mereka merasa nyaman. Konsumen dapat menimbang catnya, mengoperasikan mesin yang men-customized warna cat sesuai dengan keinginan dan memilih aroma yang mereka sukai.

\section{PENUTUP}

Experiential Marketing adalah teknikpemasaran yang menjembatani konsumen dengan merek produk perusahaan. Dulu, dalam memasarkan produk, tim pemasaran perusahaan akan mem -boom pasar dengan iklan media masa, sampling, talk show, dan sebagainya tanpa memperdulikan kondisi pasar. Di masa kini pemasar sebaiknya mulai mencari apa yang sebenarnya menjadi keinginan konsumen. karena perusahaan bukanlah pemain tunggal di pasar. Tingkat persaingan yang makin ketat membuat konsumen makin memiliki pilihan dalam memilih produk yang sesuai dengannya. Produk/merek yang berhasil dipasar adalah yang berhasil menciptakan emosional melalui pengalaman pada konsumennya sehingga menghasilkan loyalitas konsumen dalam menggunakan produk/merek.

Pendekan experiential dalam meluncurkan merek dinilai lebih efektif dan relevan dibandingkan dengan apa yang dapat ditawarkan iklan media massa. Karena dalam experiential marketing, kita perlu menciptakan persepsi konsumen yang meliputi sense,feel, think, act dan relate. Suatu merek kini harusdapat menyentuh kelima unsur ini. Konsumen mesti bisa merasakan, memikirkan dan bertindak sesuai harapannya. Bahkan jika memungkinkan, tercipta rasa memiliki terhadap suatu merek, sehingga akhirnya hal ini menjadi diferensiasi bagi merek tersebut. Ini dapat membuat konsumen (pengguna) menjadi loyalis, dan kemudian menjadi advocate. Lebih lagi, nilai merek bukan lagi hanya tergantung pada diferensiasi produknya (functional benefit), tapi juga diferensiasi dalam emosionalnya (emotional benefit). 


\section{DAFTAR PUSTAKA}

Hidayat, Taufik, 2007. “Ciptakan Great Experience”, Swa Sembada, No. 15/XXIII 12-25 Juli.

Kertajaya, Hermawan, 2007. "Ciptakan Great Experience”, Swa Sembada, No. 15/XXIII 12-25 Juli.

Kotler, Phillip \& Kevin Lane Keller, 2006. "Marketing Insight: Experiential Marketing”, Marketing Management, $12^{\text {th }}$ edition, Pearson Education, Inc., New Jersey.

Pine H, B. Joseph \& James H.Gilmore, 1999. TheExperience Economy Work is Theatre and Every Business a Stage, Boston: Harvard Business School Press

Ries, Al \& Laura Ries, 2003. The Fall of Advertising \& The Rise of PR, Terjemahan, Jakarta: Pustaka Utama.

Scmitt, Bernd H., 1999. “Experiential Marketing”, htpp://pioneer.netserv. chula.th/ ckieatvi/ Fathom_Exp_Marketing.html

Smith, Shaun \& Joe Wheeler, 2002. Managing Customer Experience: Turning Customer intoAdvocates, Great Britain: Prentice Hall.

Winarko, Bayu E., 2003. Experiential Marketing Ala Starbucks, Republika, 27 November. 


\title{
PERILAKU KONSUMEN DALAM PROSES PEMBELIAN IKAN HIAS AIR LAUT DI BANDA ACEH AKUARIUM KOTA BANDA ACEH
}

\author{
Nabila Ukhty \\ Fakultas Perikanan, Universitas Teuku Umar
}

Abstract

Competition ornamental fish in Banda Aceh increasingly stringent, requiring appropriate marketing strategies to excel compete. One way that can be taken by employers ornamental fish including Banda Aceh Aquarium, is a strategy to increase sales volume by studying and knowing the factors that influence consumers decide to buy ornamental fish. The purpose of this study was to determine (1) the consumer characteristics of ornamental fish in Banda Aceh Aquarium, (2) ornamental fish type whatever demand by consumers, and (3) factors that influence the purchase of ornamental fish in Banda Aceh Aquarium.The method used in this study is a survey method. The data will be used in this study are primary and secondary data. The sampling technique used was purposive sampling method, with a total sample of 100 respondents. Analysis of the data : (1) descriptive analysis to get an overview of consumer characteristics and type of ornamental fish that consumers demand; (2) factor analysis with factor analysis PCA extraction method. The results showed that the majority of respondents were male (71\%), aged 20-30 years $(81 \%)$, unmarried (73\%), family size 3-5 people, educated scholars (49\%), private sector employees ( $42 \%)$, and the average monthly income of more than Rp. 2,500,000. Ornamental fish species are widely purchased by consumers in the top five is Clown Fish, Blue Stone, Rivet, Beauty and Six Letter I Dori. The factors that influence consumer decisions in the purchase of ornamental fish are cultural factors, social factors, personal factors, and psychological factors.

Keywords: consumer behavior, Banda Aceh aquarium, ornamental fish 


\section{PENDAHULUAN}

Kegiatan perdagangan ikan hias air laut menjadi salah satu primadona di bidang agribisnis perikanan karena selain iklim dan sumberdaya alam Indonesia sangat menunjang, bisnis ini telah terbukti mampu bertahan di saat krisis melanda secara berkepanjangan. Perdagangan ikan hias air laut tak hanya merambah di pasar lokal tetapi juga pasar internasional. Indonesia merupakan salah satu pengekspor penting perdagangan biota laut di dunia baik dari variasi jenis maupun volumenya yang tinggi. Nilai ekspor perikanan hias Indonesia pada tahun 2009 menempati peringkat ketiga sebagai negara eksportir ikan hias dunia setelah Singapura dan Malaysia (Dewan Ikan Hias Indonesia, 2011).

Menurut Muchsin (2007), karakterisitik perdagangan ikan hias laut berbeda dengan karakteristik perdangan ikan hias air tawar. Karakteristik perdagangan ikan hias laut sangat bergantung pada pada kondisi lingkungan dan musim karena secara umum ikan hias air laut merupakan hasil tangkapan dan hingga sekarang pembudidayaan ikan hias air laut belum bisa dilakukan secara maksimal.

Banda Aceh merupakan salah satu daerah yang memiliki potensi dalam perdagangan ikan hias air laut yang ditandai dengan banyaknya masyarakat yang berusaha dengan menjual ikan hias air laut yang berdampak pada persaingan antar pengusaha. Salah satu pengusaha yang bergerak dalam penjualan ikan hias air laut adalah Banda Aceh Aquarium yang berusaha mempertahankan dan meningkatkan jumlah konsumen serta menentukan strategi untuk meningkatkan volume penjualan dengan mempelajari dan mengetahui faktor-faktor apa saja yang mempengaruhi konsumen dalam memutuskan untuk membeli ikan hias air laut.

Tujuan penelitian ini adalah untuk mengetahui: (1) Karakteristik konsumen ikan hias laut di Banda Aceh Akuarium, (2) Jenis ikan hias air laut apa saja yang diminati oleh konsumen, dan (3) Faktor-faktor yang mempengaruhi konsumen dalam membeli ikan hias air laut di Banda Aceh Akuarium.

\section{Kerangka Pemikiran}

Perilaku konsumen merupakan proses yang kompleks dan multi dimensional, karena dalam memahami perilaku konsumen banyak variabel yang mempengaruhi dimana masing- masing variabel dapat saling berinteraksi (Suryani, 2008). Menurut Engel, et al. (1994) dalam Angelina, perilaku konsumen dipengaruhi dan dibentuk oleh faktor pengaruh lingkungan, perbedaan individu, dan proses psikologis. 
Proses keputusan pembelian dimulai saat konsumen mengenali sebuah masalah atau kebutuhan. Pengenalan kebutuhan tergantung pada berapa banyak ketidaksesuaian antara keadaan yang dihadapi konsumen sekarang dan yang akan diinginkan konsumen (Kotler, 2000). Tahap berikutnya adalah dorongan pencarian informasi oleh konsumen akan kebutuhannya. Pemasar perlu memperhatikan sumber-sumber informasi utama yang menjadi acuan konsumen dan pengaruh relatif sumber tersebut terhadap keputusan pembelian selanjutnya.

Pada tahap evaluasi alternatif konsumen melakukan evaluasi pilihan produk dan merek kemudian memilih sesuai dengan yang diinginkan. Tahap berikutnya adalah keputusan pembelian. Sikap orang lain dan situasi yang tidak terantisipasi merupakan faktor yang mempengaruhi konsumen dalam tahap keputusan pembelian.

Tahap terakhir adalah perilaku pasca pembelian. Kepuasan konsumen akan membentuk keyakinan dan sikap yang berpengaruh positif terhadap pembelian berikutnya.

Perilaku pembelian konsumen dipengaruhi oleh faktor budaya, sosial, pribadi dan psikologis (Kotler, 2000).

1. Faktor Budaya : Faktor budaya merupakan penentu keinginan dan perilaku konsumen yang paling mendasar. Faktor tersebut mempunyai pengaruh yang paling luas dan dalam pada perilaku pembelian konsumen (Kotler,2000).

2. Faktor Sosial : Perilaku seseorang banyak dipengaruhi oleh kelompok kecil yang terdiri dari dua orang atau lebih yang saling berinteraksi untuk mencapai sasaran individu atau bersama. Faktor sosial meliputi kelompok acuan, keluarga, serta peran dan status sosial.

3. Faktor Pribadi : Keputusan konsumen juga dipengaruhi oleh karakteristik pribadi. Karakteristik tersebut meliputi usia dan tahap siklus hidup, pekerjaan, keadaan ekonomi, gaya hidup, serta kepribadian dan konsep diri.

4. Faktor Psikologis : Empat faktor psikologis yang mempengaruhi pilihan pembelian seseorang, yaitu motivasi, persepsi, pembelajaran, serta keyakinan dan sikap. 


\section{Kerangka Pemikiran Konseptual}

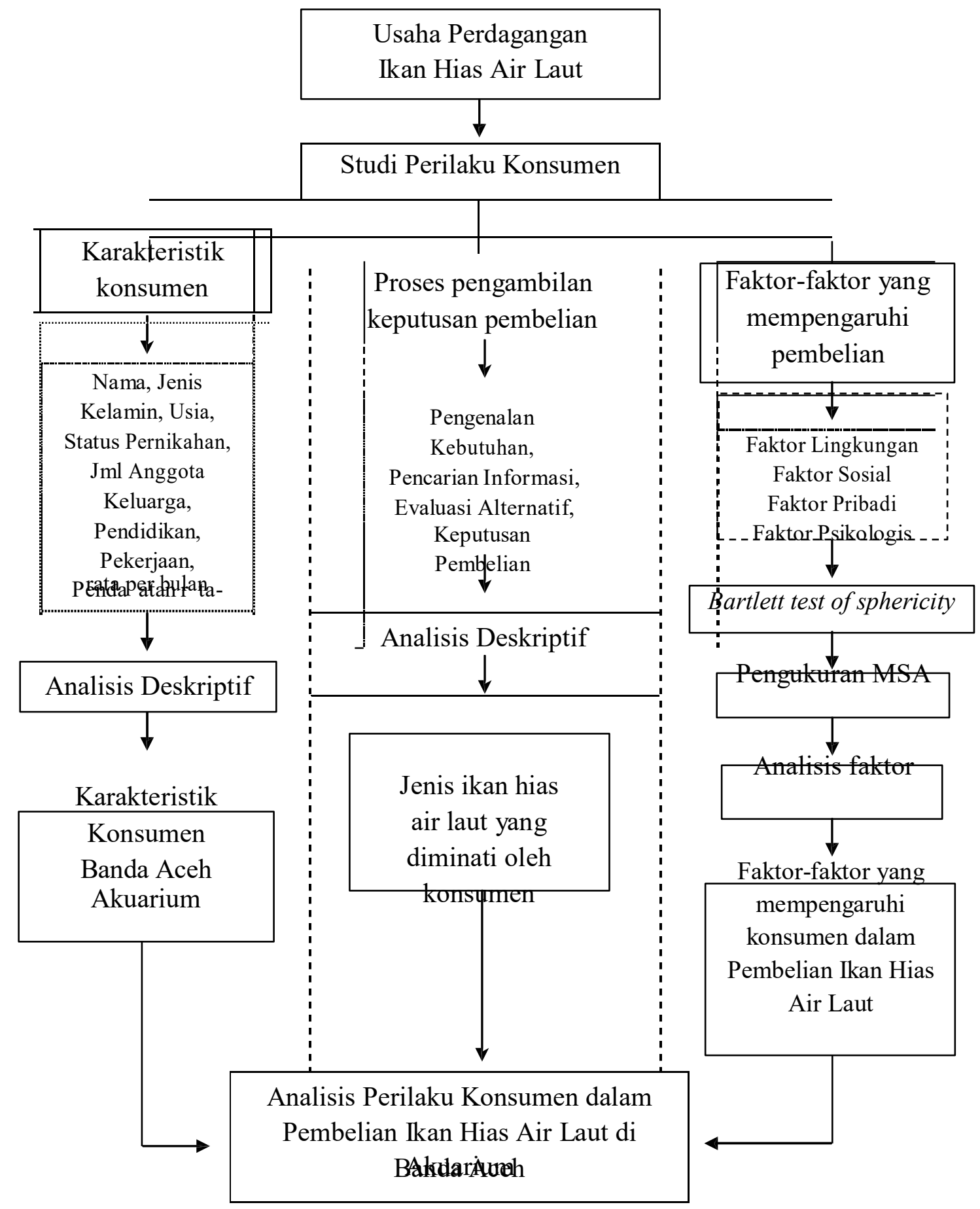

Gambar 1 Kerangka Pemikiran Konseptual 


\section{METODOLOGI PENELITIAN}

Metode yang yang digunakan dalam penelitian ini adalah metode survei. Data yang digunakan dalam penelitian ini adalah data primer dan sekunder. Data primer merupakan data yang didapat dari hasil wawancara sedangkan data sekunder diperoleh dari buku, internet serta literaturliteratur lain yang mendukung penelitian.

Teknik pengambilan sampel yang digunakan dalam penelitian ini adalah metode purpossive sampling karena peluang dari anggota populasi yang dipilih menjadi sampel adalah berdasarkan pertimbangan dan keputusan peneliti. Jumlah sampel yang digunakan dalam penelitian ini adalah sebanyak 100 orang (responden).

Variabel-variabel yang akan diukur dalam penelitian ini terdiri dari 3 bagian, yaitu :

1. Karakteristik Konsumen : (a) nama, (b) jenis kelamin, (c) usia, (d) status pernikahan, (e) jumlah anggota keluarga, (f) pendidikan, (g) pekerjaan, (h) pendapatan rata-rata per bulan.

2. Proses Pengambilan Keputusan : (a) pengenalan kebutuhan : motivasi pembelian, manfaat pembelian; (b) pencarian informasi : sumber informasi, fokus perhatian terhadap informasi yang diperoleh; (c) evaluasi alternatif : factor-faktor pertimbangan dalam melakukan pembelian, lokasi pembelian; (d) kepurusan pembelian : frekuansi, waktu pembelian, jenis ikan hias, cara memutuskan pembelian, besarnya pembelian; (e) evaluasi pembelian : kepuasan, niat membeli ulang.

3. Faktor-faktor yang mempengaruhi proses pembelian : (a) faktor lingkungan : kebiasaan orang tua, kebiasaan lingkungan, agama, tempat tinggal, budaya, dan tingkat pendidikan; (b) faktor sosial : keluarga, penjual, kerabat / saudara, teman, situasi /waktu pembelian, dan status sosial; (c) faktor pribadi : usia, pendapatan, pekerjaan, waktu luang; (d) faktor psikologis : motivasi, pengalaman, jenis ikan hias, kekhasan (warna/bentuk), harga, dan iklan

Analisis Data yang digunakan dalam penelitian ini yaitu : (1) Analisis deskriptif yang digunakan untuk mendapatkan gambaran tentang karakteristik konsumen dan dan jenis ikan hias yang diinginkan oleh responden yang dinyatakan dengan frekuensi, baik angka mutlak atau persentase, (2) Analisis faktor dilakukan dengan metode ekstraksi PCA, untuk menentukan faktor- faktor yang mempengaruhi keputusan konsumen dalam membeli ikan hias air laut

Penelitian ini dilaksanakan di Pasar Ikan Hias Rawalumbu Utara dengan mengambil kasus di Toko Ikan Hias Banda Aceh Akuarium. 


\section{HASIL DAN PEMBAHASAN}

\section{Karakteristik Konsumen Ikan Hias Air Laut di Banda Aceh Akuarium}

Karakteristik umum konsumen ikan hias air laut di toko ikan hias air laut Banda Aceh Akuarium yang diambil sebagai responden dalam penelitian ini didasarkan atas jenis kelamin, usia, status pernikahan, jumlah anggota keluarga, tingkat pendidikan, pekerjaan, dan pendapatan rata-rata perbulan.

Responden terbesar berdasarkan jenis kelamin adalah laki-laki sebanyak 71 orang (71\%), sedangkan responden wanita sebanyak 29 orang (29\%). Hal ini menunjukkan bahwa laki-laki lebih menyukai memelihara ikan hias air laut dibandingkan dengan wanita karena selain memelihara ikan, pemeliharaan akuarium harus dilakukan secara berkala dan mengeluarkan banyak tenaga.

Berdasarkan usianya konsumen Banda Aceh Akuarium mayoritas berusia muda antara 20 - 30 tahun, implikasinya penghobi ikan hias air laut lebih banyak diminati oleh kaum muda yang diduga lebih tertarik dengan kerumitan dan kesulitan dalam filtrasi air laut, dan mereka justru bisa berkreasi dalam penataan filtrasi serta penataan biota-biota lain di akuarium sebagai tempat hidup ikan hias air laut.

Status responden ikan hias Banda Aceh Akuarium sebagian besar adalah belum menikah yaitu sebesar $73 \%$, sedangkan yang sudah menikah hanya sebesar $27 \%$. Alasannya diduga bahwa orang yang belum menikah lebih tertarik dalam memelihara ikan hias air laut dalam akuarium.

Sebagian besar konsumen ikan hias air laut di Banda Aceh Akuarium memiliki jumlah anggota keluarga tidak lebih dari 5 orang. Hal itu menunjukkan bahwa dengan jumlah anak maksimum tiga orang masih mempunyai waktu luang untk memelihara ikan hias dalam akuarium secara intensif.

Tingkat pendidikan sangat mempengaruhi seseorang dalam membeli ikan hias air laut. Selain sebagai hobi dalam memelihara ikan hias, kesadaran dan pengetahuan konsumen dalam memperindah ruangan dan menata agar tempat tinggalnya menjadi lebih indah juga terbangun. Hal tersebut tercermin dari sebagian besar konsumen ikan hias air laut berpendidikan sarjana.

Karakteristik responden berdasarkan pekerjaan menunjukkan bahwa sebagian besar responden berprofesi sebagai pegawai swasta yaitu sebesar 42\%, mahasiswa/pelajar 33\%, wiraswasta 22\% dan 3\% sebagai Pegawai Negeri Sipil (PNS). Kondisi in diduga antara lain tingkat 
stress pegawai swasta lebih tinggi dibandingkan PNS sehingga diperlukan suasana yang mampu menenangkan salah satunya memelihara ikan hias air laut.

Berdasarkan tingkat pendapatan responden, sebagian besar berpenghasilan di atas Rp. 2.5 juta per bulan yaitu sebesar 56\%. Artinya tingginya pendapatan akan berpengaruh terhadap daya beli seseorang untuk membeli ikan hias air laut.

\section{Proses Pengambilan Keputusan Pembelian Ikan Hias Air Laut}

Alasan dan motivasi responden dalam membeli ikan hias air laut di Toko Banda Aceh Akuarium adalah karena hobi yakni sebesar $62 \%$ dan hanya $1 \%$ yang terpengaruh faktor harga. Hal ini menunjukkan bahwa harga suatu ikan hias air laut bukan alasan utama seseorang untuk membeli ikan hias air laut. Berapapun harga suatu ikan hias air laut akan tetap dibayar selama konsumen menyukainya.

Berdasarkan hasil penelitian, manfaat yang diharapkan responden dengan memelihara ikan hias adalah sebagai penghias rumah (65\%) dan hanya 29\% yang mengharap sebagai gaya hidup. Namun ada sebagian responden mengharap manfaat membeli ikan hias air laut ini sebagai investasi.

Tahap kedua dalam proses keputusan pembelian adalah pencarian informasi. Beberapa sumber informasi yang digunakan oleh responden untuk mendapatkan informasi tentang ikan hias air laut adalah berasal dari teman yaitu sebesar 43\%, 29\% berasal dari koran/media/tabloid/TV, dan $16 \%$ dari penjual. Peran seorang teman sangat besar dalam memberikan pengaruh sehingga konsumen tertarik untuk membeli ikan hias air laut.

Hasil penelitian menunjukkan bahwa mayoritas konsumen lebih memilih jenis ikan hias air laut (68\%). Hal ini memperlihatkan bahwa konsumen dalam membeli ikan hias air laut yang mereka inginkan tidak mempertimbangkan harga ataupun pelayanan. Kemudahan meperoleh ikan hias juga mempengaruhi konsumen yaitu sebesar 29\%. Hal tersebut menunjukkan bahwa konsumen ikan hias air laut akan berusaha mendapatkan ikan hias yang diinginkan meskipun untuk mendapatkan ikan hias air laut tergolong sulit baik karena jumlah barang yang terbatas maupun harganya yang relatif mahal.

Tahap ketiga dalam proses keputusan pembelian adalah evaluasi alternatif. Konsumen melakukan pembelian ikan hias melalui tahapan evaluasi alternatif yang manentukan seseorang untuk mempertimbangkan untung ruginya dalam membeli barang tertentu yang sesuai dengan apa yang mereka inginkan. Adapun beberapa hal yang menjadi pertimbangan 
konsumen dalam pembelian ikan hias air laut di Banda Aceh Akuarium dapat dilihat pada Tabel 1.

Tabel 1 Faktor yang Menjadi Pertimbangan Konsumen dalam Pembelian Ikan Hias Air Laut di Banda Aceh Akuarium

\begin{tabular}{llcc}
\hline No & Faktor Pertimbangan & Jumlah (orang) & Persentase (\%) \\
\hline 1 & Harga & 13 & 13 \\
2 & Jenis Ikan Hias Air Laut & 38 & 38 \\
3 & Bentuk Ikan Hias Air Laut & 14 & 14 \\
4 & Warna Ikan Hias Air Laut & 35 & 35 \\
5 & Lainnya & 0 & 0 \\
\hline & Jumlah & 100 & 100 \\
\hline
\end{tabular}

Tabel 1 menunjukkan bahwa jenis, warna dan bentuk ikan hias air laut merupakan faktor utama seseorang untuk membeli ikan hias air laut. Faktor harga bukan alasan utama seseorang dalam melakukan pembelian ikan hias aair laut. Hal tersebut terlihat hanya 13\% responden saja yang memilih karena alasan harga.

Perilaku konsumen ikan hias air laut di Banda Aceh Akuarium ketika mendapati ikan hias yang mereka inginkan tidak ada mereka cenderung akan mencari ke tempat lain yakni $46 \%$, tidak jadi membeli $26 \%$ dan membeli jenis yang lain sebesar $25 \%$.

Mayoritas pembelian ikan hias air laut di Toko ikan Hias Banda Aceh Akuarium dilakukan pada hari libur yaitu sebesar 74\%. Pembelian yang dilakukan pada hari kerja hanya sebesar $26 \%$. Pembelian pada hari libur banyak dilakukan dibandingkan pada hari kerja karena pada hari libur konsumen memiliki lebih banyak waktu luang.

Jenis ikan hias air laut yang paling banyak diminati oleh konsumen di Banda Aceh Akuarium adalah Clown Fishyakni (41\%). Clown fish (nemo) dipilih karena selain warna ikannya yang menawan, ikan ini mempunyai tingkat adaptasi yang cukup bagus dan tidak memerlukan perawatan yang spesial sehingga mudah untuk dipelihara di dalam akuarium air laut. 
Besarnya pengeluaran yang dikeluarkan oleh konsumen $\quad 71 \%$ responden mengeluarkan dana sebesar Rp. 25.000 - Rp. 102.000. Hal tersebut menandakan bahwa konsumen ikan hias air laut juga realistis terhadap harga ikan hias air laut.

\section{Faktor-faktor yang Mempengaruhi Proses Pembelian Ikan Hias Air Laut}

Tabel Anti Image Matrices pada penelitian ini menunjukkan bahwa semua variabel memiliki nilai MSA (Measure of Sampling Adequacy) lebih dari 0,5 sehingga semua variabel dapat dianalisis lebih lanjut dengan nilai communality.

Pelayanan merupakan variabel dengan communality terbesar $(0,828)$. Hal ini menunjukkan bahwa pelayanan hubungannya sangat erat dengan keputusan pembelian ikan hias air laut. Pelayanan merupakan bagian dari sikap yang ditunjukkan oleh penjual kepada konsumen yang akan mempengaruhi psikologis konsumen.

Tabel Componen Matrix menunjukkan terdapat 22 variabel yang didistribusi pada faktorfaktor yang terbentuk. Variabel-variabel tersebut menghasilkan nilai loading yang menunjukkan besarnya korelasi variabel dengan faktor yang terbentuk. Hasil Componen Matrix menunjukkan bahwa 22 variabel berkorelasi sangat kuat terhadap faktor 1 yang terbentuk yaitu kebiasaan lingkungan. Faktor-faktor yang mempengaruhi dan nilai loading komponen utama dapat dilihat pada Tabel 2 .

Tabel 2 Faktor-faktor yang Mempengaruhi dan Nilai Loading

\begin{tabular}{lll}
\hline Komponen Utama & Variabel & Nilai Loading \\
\hline Budaya & Kebiasaan Lingkungan & 0.737 \\
Budaya & Budaya & 0.721 \\
Psikologis & Motivasi & 0.687 \\
Budaya & Pendidikan & 0.686 \\
Sosial & Keluarga & 0.669 \\
Budaya & Kebiasaan Orang Tua & 0.663 \\
Sosial & Kerabat/Saudara & 0.654 \\
Sosial & Penjual & 0.651 \\
Sosial & Status Sosial & 0.650 \\
Budaya & Tempat Tinggal & 0.640 \\
Psikologis & Pelayanan & 0.630 \\
Pribadi & Pekerjaan & 0.618 \\
Sosial & Teman & 0.609
\end{tabular}


Pribadi

Usia

0.589

Psikologis

Kekhasan

0.564 


\begin{tabular}{lll}
\hline Komponen Utama & Variabel & Nilai Loading \\
\hline Psikologis & Jenis & 0.562 \\
Pribadi & Pendapatan & 0.519 \\
Budaya & Agama/Kepercayaan & 0.505 \\
Sosial & Situasi & 0.413 \\
Psikologis & Harga Ikan Hias & 0.319 \\
Pribadi & Waktu Luang & 0.314 \\
Psikologis & Iklan dan Promosi & 0.205 \\
\hline
\end{tabular}

\section{Komponen Utama Sosial}

Komponen utama sosial terdiri dari variabel keluarga, penjual, saudara/kerabat, teman, situasi/waku pembelian, dan status sosial dengan nilai loading terbesar 0,669 pada variabel keluarga. Meskipun demikian, variabel kerabat/saudara dan penjual mempunyai nilai loading dengan selisih yang tidak terlalu jauh yaitu sebesar 0,654 dan 0,651. Keluarga dapat mempengaruhi keputusan pembelian seseorang. Keluarga mempunyai pengaruh langsung maupun tidak langsung terhadap keputusan pembelian.

Pilihan konsumen terhadap suatu produk dipengaruhi oleh lingkungan yang mengitarinya. Ketika konsumen membeli suatu produk didasari oleh banyak pertimbangan, misalnya karena meniru temannya, karena tetangganya telah membeli lebih dulu dan sebagainya. Dengan demikian, interaksi sosial yang dilakukan seseorang akan turut mempengaruhi pilihan produk yang dipilih.

Pembelian suatu produk juga dipengaruhi oleh penjual yang merupakan penerapan dari strategi pemasaran. Dalam hal ini penjual berusaha mempengaruhi konsumen dengan menggunakan berbagai stimulus seperti iklan dan sejenisnya agar konsumen tertarik dan bersedia memilih dan membeli produk yang ditawarkan.

\section{Komponen Utama Pribadi}

Komponen ini disusun oleh beberapa variabel yaitu usia, pendapatan, pekerjaan, dan waktu luang. Nilai loading terbesar dalam pembentukan komponen pribadi adalah variabel pekerjaan dengan nilai 0,618 .

Pekerjaan seseorang mempengaruhi pembelian barang dan jasa. Hal tersebut berkaitan dengan pendapatan yang diterimanya. Pemasar produk yang peka terhadap pendapatan akan mengamati kecenderungan dalam pendapatan pribadi, tabungan, dan tingkat minat. Bila indikator ekonomi menunjukkan resesi, pemasar dapat mengambil langkah- langkah untuk merancang ulang, memposisikan kembali, dan mengubah harga produknya. 


\section{Komponen Utama Psikologis}

Komponen utama psikologis disusun oleh enam variabel yaitu motivasi, pelayanan, jenis ikan hias air laut, harga dan iklan. Nilai loading terbesar pada variabel ini adalah motivasi yakni sebesar 0,687. Motivasi berkorelasi sangat kuat terhadap faktor 1 yang terbentuk. Hal tersebut menunjukkan bahwa motivasi seseorang berpengaruh terhadap keputusan pembelian. Motivasi mewakili dorongan untuk memuaskan kebutuhan psikologis melalui pembelian dan penggunaan suatu produk.

\section{Komponen Utama Budaya}

Komponen budaya merupakan penyebab paling mendasar dari keinginan dan perilaku seseorang karena budaya tumbuh dalam suatu masyarakat dari sejak kecil. Komponen budaya terdiri dari variabel kebiasaan orang tua, kebiasaan lingkungan tempat tinggal, agama/kepercayaan, tempat tinggal, pendidikan dan budaya. Nilai loading terbesar pada komponen ini adalah variabel kebiasaan lingkungan tempat tinggal dengan nilai sebesar 0,737. Hal tersebut menunjukkan bahwa kebiasaan lingkungan tempat tinggal konsumen dalam menata ruangan tempat tinggalnya agar senantiasa menarik dan indah dengan menghadirkan akuarium ikan hias air laut.

\section{SIMPULAN}

Mayoritas responden adalah laki-laki (71\%), berusia 20-30 tahun (81\%), belum menikah (37\%) anggota keluarga 3-5 orang (73\%), berpendidikan sarjana (49\%) karyawan swasta (42\%), dan pendapatan rata-rata perbulan lebih dari Rp. 2.500.000. Jenis ikan hias air laut yang banyak dibeli oleh konsumen dalam lima besar adalah Badut/Clown Fish, Blue Stone, Keling, Cantik dan Letter Six/Dori. Faktor-faktor yang mempengaruhi keputusan konsumen dalam pembelian ikan hias adalah faktor budaya, faktor sosial, faktor pribadi, dan faktor psikologis. Variabel-variabel yang mempengaruhi proses pembelian adalah kebiasaan orang tua, kebiasaan lingkungan, agama, tempat tinggal, budaya, tingkat pendidikan, keluarga, penjual, kerabat/saudara, teman, situasi/waktu pembelian, status sosial, usia, pendapatan, pekerjaan, waktu luang, motivasi, pelayanan, jenis ikan hias air laut, kekhasan, harga, dan iklan. Sebaiknya dilakukan penelitian lanjutan untuk melihat keberhasilan strategi pemasaran ikan hias air laut dan apakah faktor manajerial dapat mempengaruhi keputusan pembelian. 


\section{DAFTAR PUSTAKA}

Anggraeni, Putu Widyastuti. 2004. "Pengusahaan Ikan Hias Laut secara Berkelanjutan" Tesis Ilmu Lingkungan, Universitas Indonesia.

Dewan Ikan Hias Indonesia, 2011, "Dewan Ikan Hias Indonesia” http://www.perikananbudidaya.kkp.go.id /index.php?option=com_content\&view=article\&id=333:dewanikan-hias-indonesia\&catid=148:sekretariat\&Itemid=144. Didownload pada bulan November 2012. Diakses pada Bulan Desember 2012

Kotler, P. 2000. Marketing Management, Prentice-Hall, Inc. Upper Saddle River, New Jersey

Muchsin, Musliyadi. 2007. Analisis Kepuasan Pengunjung Toko Ikan Hias Air Laut Tropical Akuarium di Kotamadya Bogor. Skripsi Manajemen Agribisnis, Institut Pertanian Bogor.

Nugroho J. Setiadi, 2005. Perilaku Konsumen, Konsep, dan Implikasi untuk Strategi dan Penelitian Pemasaran, Penerbit Prenada Media, Jakarta.

Santoso, Singgih. 2012. Aplikasi SPSS pada Statistik Multivariat. PT Elex Media Komputindo Gramedia. Jakarta.

Sembiring, BR Angelina. 2006. Analisis Perilaku Konsumen dalam Proses Keputusan Pembelian Makanan di Restoran Bakmi Japos Bogor. Skripsi Ekonomi dan Manajemen, Institut Pertanian Bogor.

Simamora, Bilson. 2004. Riset Pemasaran-Falsafah, Teori dan Aplikasi, Penerbit PT Gramedia Pustaka Utama Jakarta.

Suryani, Tatik. 2008. Perilaku Konsumen-Implikasi pada Strategi Pemasaran, Penerbit Graha Ilmu, Yogyakarta 